\title{
DrifTING Apart? The Institutional Dynamics Awaiting Public Sociology IN CANADA
}

\author{
Scott Davies
}

\begin{abstract}
Michael Burawoy offers an innovative call to reintegrate our discipline. Using Canada as an example, I argue that his proposal underestimates the extent of institutional separatism among branches of sociology. Influenced by antipositivist currents in the humanities over the past two decades, critical sociologists are disconnecting from mainstream empirical research. Simultaneously, the mainstream is moving in a very different direction as it responds to developments in other social sciences, and largely ignores the humanities. I hypothesize that this institutional drift limits the possibility of mutual correction between various branches of sociology, a process that is central to Burawoy's proposal. Possible scenarios for the future of public sociology in Canada are discussed in light of this hypothesis.
\end{abstract}

Keywords: public sociology; critical sociology; disciplines; research

Résumé. Michael Burawoy lance un appel avant-gardiste à réintégrer notre discipline. Or, prenant le Canada à titre d'exemple, l'auteur soutient que sa proposition sous-estime l'étendue du séparatisme institutionnel des différentes branches de la sociologie. Il explique que les sociologues critiques sont en train de se couper du courant principal de la recherche empirique, après avoir été influencés par les courants antipositivistes dans les humanités au cours des deux dernières décennies. Pendant ce temps, le courant principal se déplace dans une autre direction, à cause de l'influence de changements très différents dans les autres sciences sociales. L'auteur émet l'hypothèse que ces tendances séparées réduisent la possibilité de loyauté mutuelle entre les diverses branches de la sociologie, un processus qui est fondamental dans la proposition de Burawoy. Il discute de scénarios possibles pour l'avenir de la sociologie publique au Canada à la lumière de cette hypothèse.

Mots clés: sociologie publique; sociologie critique; disciplines; recherche 


\section{Introduction: Mutual Correction in Sociology?}

Cociology enjoys little consensus over its fundamental standards, methods and theories, or the role of politics in its scholarship. Debates over these issues have inflicted battle scars that date back several decades. While other fields, such as anthropology and English, are also conflict-ridden, sociology's angst is unique, reflecting its singular attempt to straddle the humanities and social sciences, and its uneasy identity as a science, humanistic pursuit, or some sort of hybrid. ${ }^{1}$ A sprawling "what's wrong with sociology" literature has described these problems in lurid detail, but has not mended one of its prime fault lines: the split between "critical" and "mainstream" approaches. As I elaborate below, over the decades, critical sociologists have launched a litany of criticisms, variously accusing the mainstream of being intellectually barren, philosophically naive, outmoded by recent literary fashions, apolitical and irrelevant, inherently reactionary and oppressive, or simply boring and aesthetically unappealing. Mainstreamers in turn see critical approaches, when taken to their antipositivist extreme, as becoming empirically inaccurate and detached from the real world. ${ }^{2}$

Some may argue this discord has not been fatal for Canadian sociology. Indeed, in the 1960s and 1970s, when most sociology departments in Canada were founded, university administrators largely tolerated such fights as the growing pains of a feisty yet popular discipline, especially since student enrolments were healthy, and since there were few immediate competitors for scarce academic funds. Some even saw those disputes as a source of intellectual vitality; but, decades later, that academic climate is fading. Fewer administrators have the patience to settle any departmental wars that may erupt, and they are increasingly on the lookout for opportunities to divert resources elsewhere, especially to fashionable interdisciplinary or commercially oriented programs.

In this context, Michael Burawoy's (2005a) proposal for public sociology is a welcome, refreshing, and potentially energizing reflection on the state of the discipline. Burawoy argues that changes in the academy and the world at large require sociologists to speak with a more united voice if their discipline is to survive intact. His proposal is essentially a peace accord to unite a discipline that, in many universities, is becoming increasingly marginal, and in some, is threatened with dissolution. Burawoy has sketched a blueprint for integrating our professional, critical,

1. Anthropology has similar challenges of integrating the science-oriented areas of archaeology and physical anthropology, and the (now) postmodernist fields of cultural and social anthropology.

2. For compendiums of these varying positions, see Agger (2007) and Horowitz (1993). 
policy, and public camps. He envisions a division of labour in which each camp corrects the others' pathologies, and by doing so, revitalizes the discipline as a whole, while allowing us to speak collectively to an array of caring publics. Though this proposal blends an enthusiasm for public and critical sociology with some charitable words for the mainstream, it has generated much debate. Indeed, a veritable cottage industry of commentary has emerged from the pages of The American Sociologist, Social Forces, Sociology, Current Sociology, British Journal of Sociology, Social Problems, and Sociological Theory. ${ }^{3}$ Much of this discussion has centred on strategies to engage the discipline's external audiences, and virtually all participants want sociology to have a better public profile and relevance. But it is clear that a diverse array of commentators have sharply differing assessments of how a new public sociology might affect the discipline's internal dynamics. These splits hinge on each commentator's stance vis-à-vis the professional core of sociology. On the one side, commentators such as Joan Acker (2005) and Ulrich Beck (2005) applaud public sociology as a potential counterweight to an irrelevant and outmoded mainstream, while being skeptical of the latter's capacity to reform itself. ${ }^{4}$ On the other side, doubters such as Steven Brint (2005), Mathieu Deflem (2007), Neil McLaughlin and his colleagues (2005), Francois Neilson (2004), and Jonathan Turner (2005) worry that any further diversion of resources from sociology's professional core will only undermine the discipline in today's academe, especially in nations where it has shallower roots and weaker boundaries.

While Burawoy's proposal is well-meant and displays a deep knowledge of American sociology, I tend to side with the latter set of commentators, contending that his proposal may not be suitable for Canadian sociology at this time. In this essay I argue that if public sociology is to unite our discipline and foster a virtuous circle of self-correction among its four wings, it must address a growing separation of critical from mainstream sociology. I argue that twin institutional pressures are balkanizing rather than integrating the discipline, pulling those camps in different directions, and limiting possibilities for any mutual correcting. In one direction, critical sociologists who espouse various forms of antiposi-

3. Michael Burawoy's website (http://burawoy.berkeley.edu/PS.htm) offers links to at least four edited collections on public sociology, and over one hundred journal articles and book chapters on the topic, virtually all of which have been published over the past four years.

4. Beck (2005:335) tempers his excitement at the prospect of public sociology with the following: “... I don't think mainstream sociology is really prepared for this adventure ... all the different forms of public and non-public sociology are in danger of becoming museum pieces. Thus, sociology not only needs a public voice, it needs to be re-invented first - in order to have a public voice at all!" On p. 342 he adds: "In this global era, sociology urgently needs a New Critical Theory with cosmopolitan intent." 
tivism are increasingly influenced by developments in the humanities, particularly literary criticism, cultural studies, cultural anthropology, social history, and social philosophy. In the other direction, professional or "mainstream" sociology is increasingly attuned to developments in other social sciences such as economics, psychology, and political science that mostly encourage an increasingly scientific outlook and prioritize methodological techniques and evidence-based interventions. While this split is hardly new, I contend that it is hardening, with mainstream and critical sociologists each forming their own academic venues, intellectual habits, publishing outlets, course labels, and hiring categories. This separation is a product of academic institutionalization, in which intellectual stances eventually become routine, habitual and taken for granted, less reflective or deliberate, and adopted to signal professional allegiances. I contend that any promotion of public sociology in Canada would need to address these realities in reintegrating the discipline. In the next section I define the key terms "critical and "mainstream" in order to set up the remainder of the argument. ${ }^{5}$

\section{Defining Terms: Critical and Mainstream ${ }^{6}$}

How can we meaningfully distinguish "critical" from "mainstream" sociology? Both terms are frequently invoked and highly ambiguous. For instance, a majority of Canadian sociologists describe themselves as "critical" (Michalski 2005), but this may reflect the term's multiple meanings, and the tendency for social scientists to use it mainly as an honorific term of self-identification (Hammersley, 2005). One mean-

5. Though it offers many examples, this essay is not based on a systematic study. Like others in this genre, it is a broad-stroked opinion piece that mixes sociological ideas with personal impressions. I readily concede that its claims are speculative and provisional, and invite others to examine them further with data. I recommend comparisons of citation patterns, supplemented with content analyses, and/or interviews with adherents of each camp. Quantitative analyses could borrow methods developed by Hargens (2000) and Moody (2004). Lamont and Molnar's (2002) framework for "social boundaries" could inform content analyses. And, to clarify, I am not arguing that the critical-mainstream split is the lone source of discord in the discipline, but rather that it is a major obstacle to its reintegration.

6. For two reasons I use the term "mainstream" instead of "professional sociology" in the remainder of this essay. First, commentators such as Ericson (2005) worry that the latter implies that sociology's other camps are unprofessional, i.e., that they lack rigour, erudition, substance, etc. While that is far from Burawoy's intent, the term "mainstream" is more neutral, and is arguably more meaningful to sociologists (though "mainstream" too has had loaded meanings in the history of American sociology, see Calhoun and Antwerpen 2007). Second, as I argue below, critical sociology has become an alternative professional venue in its own right, and hence another term is needed to distinguish it from Burawoy's professional sociology. 
ing centres on "critical thinking" in the sense of rigorous examinations of preconceptions and assumptions, and explorations of alternative research interpretations. But since all sociologists lay claim to those ideals, that usage cannot capture key divides in the discipline. Another meaning associates critical perspectives with left-wing political stances, but that too fails to capture core divisions, since as Burawoy (2005a) and other leftists attest (Agger 1991; Calhoun and Antwerpen 2007; Steinmetz 2007), the mainstream has long been liberal and progressive, and may be increasingly so. Burawoy's (2005a) definition is more exacting: he equates a critical stance with reflexivity, and a distinct task of deliberating the ultimate purposes of sociological research. Yet, it is difficult to identify critical sociology with reflexivity, since concrete descriptions of sociological reflexivity are rare, and often lack clarity (for a catalogue, see Bourdieu and Wacquant 1992). ${ }^{7}$ The term "reflexivity" seems to describe an ideal state of self-consciousness rather than a set of identifiable practices to distinguish one kind of sociologist from another; uses of the term reflexivity can devolve into pejorative labels of praise or denigration. To better distinguish the critical from the mainstream, therefore, we should identify differences that are actually consequential for sociological practice.

I argue that a surer source of difference is rooted in disputes over positivism, empiricism, and scientism. Two overarching intellectual templates emerged from mid 20th century debates between scientific sociologists and followers of the Frankfurt School (Bottomore 1984; Kolakowski 1978). While the particular details of those debates are now old and largely forgotten, they have since been institutionalized in nations like Canada, where critical antipositivists take their inspiration from the humanities, and mainstreamers orient themselves to the social sciences. This consequential split shapes their identities, types of sociological practice, and criteria for assessing the value of academic work. ${ }^{8}$

This argument draws on notions of academic institutionalization how systems of thought attain normalized routines, organizational supports, career reward structures, and a taken-for-granted character. For instance, few of today's mainstream sociologists dwell on issues of philosophy of science, a contrast from the heyday of Paul Lazersfeld. Few self-identify as "positivists," and even fewer would trace their work to

7. Perhaps reflexivity could enter Burawoy's framework as an ideal for curbing pathologies - for mainstreamers to guard against insularity, for the critical camp to avoid dogmatism, for the policy-oriented to take heed of servility, and for public sociologists to beware the temptations of faddishness.

8. Another qualification: I am using an ideal-typical binary for the sake of clarity, but acknowledge that tendencies towards the humanities or social sciences may lie on a continuum, or assume a fractal character when closely inspected (see Abbott 2004). 
the writings of the Vienna Circle. Instead, most are content to assume that there is a reality "out there" to be conceptualized, measured, quantified, and tested. They treat philosophies of science as a speciality of social theorists with little bearing on their day-to-day research. Likewise, most critical sociologists now take critiques of positivism and empiricism to be self-evident, and rarely see a need to closely read the works of the Frankfurt School, as did a previous generation. Today's critical sociologists instead adopt those ideas as a "repertoire" of stances that distinguish their work from the mainstream.

This repertoire has several connected, yet not entirely compatible emphases. First is a "historicist" tendency to rule out positivist hopes of discovering universal social processes that transcend time and space. This position is used by critical sociologists who favour historical research over "presentist" sociology (for a debate, see Goldthorpe 1994). Second is a "subjectivist" tendency that rejects the objectivity of social science and dismisses the use of finely tuned methodological procedures for verifying knowledge claims (see Agger 1991). This tendency is strongly influenced by the much vaunted "cultural turn" in humanities such as anthropology, literary theory, and history that promotes sundry qualitative and sometime relativist approaches, particularly postmodernism and theories of subaltern identities. Third is a philosophical antipositivism that attacks "empiricists" who merely assume that "facts are out there." This interpretive critical sociology sees mainstream research strategies as logically untenable and moribund (e.g. Bryant 1992), and gravitates towards philosophy-oriented, social metatheory. Finally, a political version portrays positivism as inherently conservative and naively accepting of the status quo. This Frankfurtian position is ubiquitous today, and assumes a variety of guises - Marxist, feminist, antiracist, and sometimes a combination of each (such as Wacquant's [2002] missive against prominent American ethnographers). This tendency orients critical scholars away from "normal science" mainstream research and towards social criticism. Each stream of antipositivism provides material for niche-making within the discipline, and encourages its adherents to seek more intellectual inspiration from the humanities rather than from the social sciences.

Having defined terms, I elaborate the institutional component of my argument, and then conclude the essay by outlining alternative scenarios for public sociology in this country. 


\section{From a Contested yet Common Arena to Separate Spheres}

Ideal-typical science separates ideology and knowledge, opinion from fact. Critical sociologists have long declared such distinctions to be wrongheaded at best and politically dangerous at worst. A short list of catchphrases offers a reminder of American versions of these longstanding and unresolved quarrels: Whose side are we are on? Knowledge for what? Knowledge for whom? Can sociology be value-free? Despite their acrimony and bitterness, these disputes did not greatly dis-integrate the discipline until the 1980s and 1990s. Interestingly, the battles between critical sociology and the mainstream during the 1960s and 1970s were more bridgeable, even though they spoke to deeper real-world political rifts than do today's disputes (for a series of examples, see Calhoun and Van Antwerpen 2007). Being a relatively smaller field than it is today, American sociology was more contested and relatively more cohesive. Critics surely assailed the mainstream, but they did so in the pages of American Sociological Review. They may have loudly voiced their complaints, but did so at the annual meetings of the American Sociological Association. Followers of Paul Lazersfeld, Talcott Parsons, Robert Merton, James Coleman, C.W. Mills, Howard Becker, Harold Garfinkle, and Immanuel Wallerstein may have disliked one another, but all of these leading combatants were very familiar to and much read by both sides. The toppling of the functionalist paradigm, which before the 1970s served as an intellectual glue for the discipline, did not lead to total disintegration. American sociology instead reinvented itself as a multimethod, multiparadigm discipline. It became a big tent. Marxist, Weberian, feminist, and "conflict" approaches competed for breathing space; qualitative and interpretative methods were given a new life alongside statistical procedures; and proponents of feminist and racial minority movements launched research programs in gender, race, and social movements (for a discussion, see McAdam 2007). Even though there was much professional infighting and turmoil, sociologists were able to claim a fair amount of common ground. They fought over which methods best depicted reality and which topics most directly addressed burning political issues, but did so in a shared arena of evidence-based discourse. One could challenge the mainstream by studying "new" topics like gender discrimination while freely borrowing from the widening array of sociological tools, or approach established topics in new ways. This pragmatic arrangement allowed sociologists to disagree over their choice of methods or political attachments while sharing some common ground. 
Consider two "critical" books, both written in the 1970s, that were hugely influential in the mainstream. Harry Braverman's Labor and Monopoly Capital (1974) was celebrated by Marxists for its challenge to the prevailing functionalist paradigm in the sociology of work and industry, and its identification of "de-skilling" as a central dynamic of capitalism, soon leading to the birth of labour process theory. But Braverman's intervention was also taken seriously by mainstreamers, since it was rooted in evidence and a close reading of major mainstream approaches. His book thus served to "correct" mainstream sociology of work, and in its turn was subjected to test and corrective refinement. Similarly, Samuel Bowles and Herbert Gintis' Schooling in Capitalist America (1976) - still regarded as the Marxist treatise on education confronted prevailing frameworks for understanding school attainment. They reinterpreted mainstream social science as exaggerating the role of natural intelligence and merit-based sorting in schooling, and underestimating how social class shapes educational opportunities. Both books soon entered the mainstream "canon" in stratification, work, and/or education. Like other Marxists of that stripe, those authors believed that science could be a tool of working class empowerment, and that it could speak truth to power. They criticized sociology for its substantive content rather than its broad methodological orientation. While both books were distinctly "critical" in their use of Marxist theory to guide their research questions and interpretations, neither ignored the mainstream, claimed to reject science, or took philosophical excursions about the nature of reality, ways of knowing, or the wonders of postenlightenment epistemes. And, maybe not coincidentally, both books were lucidly written.

This integrated version of American sociology provided the organizing template for the dozens of sociology departments that were launched across Canada in the 1960s and 1970s. Scholars who may have been political radicals were encouraged to engage the mainstream with evidencebased forms of debate. Perhaps a prime example was the oeuvre of John Porter. His Vertical Mosaic has long been seen as the classic of early Canadian sociology. It simultaneously won the ASA book of the year award in 1966 and galvanized a left-wing research tradition in social inequality. Canadian sociologists in both critical and mainstream camps each proclaimed Porter as their own. Porter fathered Canada's Marxist political economy tradition and its mainstream research in status attainment, with both progeny having since been "corrected" in intriguing ways (for discussions, see Helmes-Hayes 2002; Ogmundson 2002).

In turn, the mainstream was certainly responsive to its critics, and a topic-driven process of "correction" occurred. Feminists largely introduced the study of gender and women, and led research on topics ran- 
ging from wage gaps and workplace discrimination to family dynamics and domestic violence to social movements and activist organizing. Sexual minorities helped established the new sexuality studies, and Marxists reinvigorated all aspects of the study of social class. Major figures and their ideas in each of these newer areas became well-known in the mainstream. Of course, some proponents claimed that the real revolution was still to come, and demanded that sociology overhaul its intellectual core in order to fully welcome their worldviews. They faulted the discipline for incorporating these challenges in piecemeal fashion, whether by merely "tacking on" women to prevailing research strategies, by marginalizing these new areas, or by reducing Marx's influence to a generic "conflict theory" (e.g., Stacey and Thorne 1986; Ferree et al. 2007; Winant 2007). Such views notwithstanding, the mainstream was undoubtedly influenced by critical sociology between the 1960s and the 1980s.

This image of a well-integrated discipline appears to underlie Burawoy's current proposal. Indeed, it may accurately reflect what the discipline was like in Canada during the 1970s. Then, most Canadian sociologists had some familiarity with the renowned American mainstreamers of that era, such as Coleman, Gouldner, Becker, Merton, and Blumer. While sociology north of the 49th parallel was influenced by a left nationalist movement that demanded more purely Canadian content and approaches (Cormier 2004) one could argue that the emerging publishing venues, courses, and hiring categories reflect a fair degree of disciplinary consensus.

\section{Signs of Drift: Institutionalizing an Old Fault Line}

Burawoy's (2005a) essay signals his considerable knowledge of the mainstream, and even some admiration for it. But does his portrait of the discipline provide a good mirror of Canadian sociology today? Are critical sociologists reading the mainstream, and following its developments? It is not clear whether many critical, antipositivist sociologists north of the border have even heard of major contemporaries in the ASA, such as Paul DiMaggio, Woody Powell, Ann Swidler, Diane Vaughn, Randall Collins, John Meyer, Neil Fligstein, Michele Lamont, Frank Dobbin, Doug McAdam, or Vivianna Zelizer. And in turn, it is unclear whether critical heroes such as Jean Baudrillard, Judith Butler, Jacques Derrida, Jürgen Habermas, Michel Foucault, Clifford Geertz, Dorothy Smith, and Jacques Lacan are influential in the mainstream. They may be read within the confines of theory courses, and mainstreamers may be broadly aware of their broad stances, but do they generate mainstream 
research programs, and thus "correct" the mainstream? Is the mainstream compromising its orientation to science in order to appease those critics? Below I argue that the reward structures facing each branch of sociology are evolving in different directions, and as a result, each is increasingly immune from most of the doubts and criticisms of the other, thus narrowing the possibility of mutual correction.

\section{Institutional Venues: Hires, Textbooks, Graduate Programs, FUNDERS}

Canadian sociology in the 1970s and 1980s was organized into areas familiar to most ASA mainstreamers. Labels for courses and hiring abounded in areas like Theory, Methods, Deviance, Work and Occupations, Stratification, Organizations, Gender, Sociological Theory, Family, Socialization, and so on. Some departments continue today to advertise in those areas, or recruit in newer branches of the mainstream like social networks, economic sociology, and sociology of culture. During those previous decades, one could be critical or mainstream and be hired in one of those generic job categories. But trends in Canadian sociology over the past 20 years lend the impression that established job categories are disappearing, and new categories are emerging, such as "moral regulation," "social justice," "social exclusion," "equity studies," or "social theory," along with explicit language that requires candidates to adopt a critical approach.

To test this hunch, I examined all tenure-stream jobs advertised by sociology departments in The CAUT Bulletin between May 2005 and January 2008. From a total of 92 unique listings, I coded 57 as using generic, mainstream categories, 26 as using "critical" categories, and 9 that were clearly interdisciplinary. ${ }^{9}$ Mainstream categories included research methods, and the sociologies of the family, deviance/criminology, social movements, education, rural societies, gender. In contrast, critical categories used longer and more detailed terminology to signal their preferences. At least 7 ads contained the term "critical" to describe their area, as in "critical criminology." The phrase "social justice" appeared in 6 ads, which is far more than the term "social stratification." Some ads used terms like "self and subjectivity," while none adopted the social science term "social psychology." Some described "theory" in new,

9. My most pivotal coding decision centred on theory positions. I counted advertisements for "sociological theory" and "social theory" as mainstream and critical, respectively, reasoning that the former conveys a preference for the unique tradition associated with mainstream sociology, and that the latter conveys a preference for interdisciplinary theories associated with critical approaches. 
elaborate ways, such as "power, knowledge, empire, visual sociology," and "culture and identities, constructionism and post colonialism." One position was worded as "racialization" rather than the standard "race and ethnicity." Thus, while a minority of sociology positions are advertised with a uniquely critical language, it is a sizeable minority that appears to be growing..$^{10}$ Some emerging fields in sociology are increasingly distinguished as "critical," and may be detached from the discipline's established traditions. Importantly, this trend does not simply reflect the spread of interdisciplinary pressures, since I did not detect similar trends in social sciences like economics and psychology. In those disciplines, job categories appear to be more stable, reflected by the many ads in labour economics, international economics, microeconomics, and public economics, or developmental psychology, clinical psychology, or cognitive psychology.

A parallel trend can be detected in publishing. Virtually every course area in Canadian sociology now has a separate "critical" textbook, ranging from introductory sociology (Steckley and Letts 2006), to sociology of education (Wotherspoon 2004), to criminology (Dekeseredy and Perry 2006), to work (Rinehart 2005), to race and ethnicity (Satzewich and Liodakis 2006), to organizations (Mills, Simmons, and Helms Mills 2005), to family (Cheal 2003) and even to methods (Kirby, Greaves, and Reid 2006). This is just a sampling - in some areas, the self-labelled "critical" offerings outnumber the mainstream books. While journals like Canadian Journal of Sociology and Canadian Review of Sociology continue to publish a variety of material, journals like Critical Sociology, New Left Review, and Studies in Political Economy are known to be exclusively critical, and book sellers like Black Rose, Garamond, and Fernwood are also known to be primary outlets for scholars who are critically oriented. Many Canadian mainstreamers, in contrast, read and publish in ASA journals and some American regional journals, sometimes deeming those outlets to represent a "gold standard" of sorts, an evaluation that is hotly rejected by the critical camp.

One can also see manifestations of this gap in graduate programs. I examined four sociology programs in Canada's largest cities: University of Toronto, York University, The Ontario Institute for Studies in Education, and McGill University. The University of Toronto and York University represent two of Canada's largest graduate programs. While all

10. This drift is not the only story. There is also a near-disappearance of positions in many substantive areas of the discipline beyond theory, methods, gender, or criminology. Few are advertised for once prominent areas, such as political sociology, work and occupations, education, religion, or social psychology. Perhaps departments are using hires in theory and methods to staff those substantive courses, but such a trend would underscore the low priority accorded to those research areas. 
of these departments offer requisite courses in areas like classical theory, qualitative methods, ethnic relations, and gender, from there many key differences emerge. The mainstream University of Toronto program has multiple statistics courses, and offerings like network analysis, political sociology, mental health, ethnicity, deviance, and religion, as well as relatively new mainstream areas like sociology of culture. In contrast, York's program does not list a statistics course, and instead covers areas that are not normally recognized as mainline sociology, such as "critique of everyday life," "theories of cosmopolitanism," "contemporary indigenous and sociological thought," "critical science and technologies studies," "transnational sexualities," and "violence, identity, and subjectivity." While the latter trend may reflect a healthy tendency to crosslist courses in an interdisciplinary spirit, it is worth noting that none of the York courses are cross-listed with social sciences such as economics or psychology. A very similar pattern emerges by comparing sociology programs at OISE versus McGill: statistics and other traditional courses abound at McGill, but are largely absent at OISE.

While some differences across graduate programs are to be expected in any discipline, these examples illustrate the profound points of departure within Canadian sociology. Given that graduate programs provide students with their primary professional orientation to the field, large differences among them may signal a lack of integration of the discipline. A program that does not offer a statistics course, for example, may not prioritize the training of students to pen studies for any of the major ASA journals, or the European Sociological Review, or even interdisciplinary outlets such as Canadian Public Policy. Likewise, a program that has meagre offerings in contemporary social theory likely has little interest in the critical humanities.

Funding represents another disconnect between these branches of sociology. Many critics over the past quarter of a century have declared all forms of positivism to be untenable, but during that time social science research has grown and prospered. In Canadian sociology, the basic model of mainstream research continues to survive (Gartrell and Gartrell 1996). "Positivist" research has proven to be quite durable, easily surviving its dismissal by social theorists, and even prompting some puzzlement over its surprising longevity (e.g., Steinmetz 2006; 2007). How, in sociological terms, does positivism persist? Perhaps the prime reason is that mainstream sociology easily finds institutional support within most universities and the surrounding research sector. To state the obvious, few university administrators or major funding bodies have embraced antipositivism. To the contrary, mainstream social science has highly institutionalized categories, standards of evaluation, and norms 
that immunize it from most attacks from the critical camp. Most funders and administrators welcome social research that is guided by testable empirical propositions, and are unconcerned by metatheoretical doubters. If mainstreamers wish to seek guidance on the broad social implications of their research, they can turn to friendly institutional venues. All universities have research ethics offices with professional staff and formalized procedures. Granting agencies leverage research on issues with public relevance and policy importance. Applicants are advised to communicate their results to nonacademic audiences. Thus, any mainstreamer who may be confused about the societal implications of their research can turn to these established venues and readily consult ethics officers, policy experts, and their public partners if they so choose, and disregard any excessive antipositivist criticism. Given these options, the worldview of Social Text, for instance, may seem less than compelling.

In sum, the examples in this section suggest that Canadian sociology departments are offering an alternative career path to critical scholars who are influenced by the humanities, while retaining social science paths for mainstreamers. As I further argue in the conclusion, this split may become a source of rivalry for scarce academic resources, and any proposal for public sociology will need an antidote to this tension.

\section{Theory: Explaining versus Metatheorizing}

Mainstream and critical sociologists share a lineage of classical sociological theorists. While scholars may deem the relative importance of Marx versus Weber, Durkheim, or Simmel somewhat differently, classical theory offers much common ground. But the realm of contemporary theory tells a different story. Mainstream theorizing is explanatory, synthetic, "middle range," and responsive to quantitative research, exemplified by approaches such as expectations states, exchange theory, rational choice, and rational action theory, as well as sundry interpretative approaches like symbolic interaction, ethnomethodology, and dramaturgical analysis. In comparison, contemporary critical theory is influenced far more by the "cultural turn" in literary theory, cultural anthropology, social history, social philosophy, and the identity-based theories of feminists, postcolonialists, and antiracists. Since the 1980s, when Marx began to slip as the guiding figure for the critical camp, more "philosophical" theorists such as Michel Foucault and Jürgen Habermas have risen in prominence (for some evidence, see Gene Expression 2008). As Marxism withered, a new generation of critical sociologists grew less attuned to social science models of empirical research, and more attuned to the 
humanities. Cultural anthropologists offered a rationale for rejecting explanations in favour of thick descriptions, along with a moral argument for allying with the everyday, local ways of knowing of the downtrodden. Postmodernists took that sentiment in an even more obtuse direction, using literary criticism to portray sociological research as merely one of many forms of discourse about society, with no greater claim to intellectual authority than rumour, gossip, or folklore. Foucaultians posed questions that were difficult to answer with mainstream research (Fox 1998). ${ }^{11}$ As metatheorizing about the condition of society, knowledge, and subjectivity expanded, social theory became a separate speciality in its own right, one that was largely detached from sociology's mainstream traditions, and from any functioning division of labour in the discipline. By establishing new journals and presses, critical sociologists created their own institutional platform, one from which they could ignore criticisms of their "nonscientific" status, and portray the mainstream as an irrelevant anachronism.

\section{Methods: Techniques versus Politics}

As discussed above, sociology in the 1970s reinvented itself as a multiparadigm, multimethod discipline. Today most mainstream departments offer general courses covering several research methods, and/or specialist courses in both qualitative and quantitative approaches. Textbooks such as the numerous editions of Earl Babbie's The Practice of Social Research (2006, in its 11th edition at last count) extol the virtues of all approaches, calmly detailing the strengths and weaknesses of each, and presenting choices between methods as a series of tradeoffs. Qualitative approaches are seen to offer depth and validity, while quantitative strategies are suited for breadth and generalizing. Researchers are advised to choose the method that best suits their research question. Pluralism and ecumenism, not purism, is the stuff of the sermon. Critical sociologists in the 1970s and into the 1980s also embraced this pluralism of quantita-

11. Despite his own efforts, Agger (1991:125) does not offer a coherent vision for the integration of critical, poststructural, and postmodern theories into the mainstream: "For mainstream sociology to adopt, and thus adapt to, these three theoretical perspectives would substantially change the nature of the discipline. At some level, the notions of poststructural and postmodern sociology are oxymorons: Postmodernism and poststructuralism, like critical theory, resist their integration into a highly differentiated, hierarchicalized, technical discipline that defines itself largely with reference to the original sociologies of Comte, Durkheim, and Weber, who established the positivist study of social facts and separated the vocations of science and politics." Agger then goes on to champion multidisciplinary research, but every discipline he mentions is either rooted in the humanities or the new identity studies (e.g., women's studies, ethnic studies) rather than social sciences such as political science, economics, or psychology. 
tive, qualitative, and historical studies, with various types of Marxists embracing survey, ethnographic, or historical trends. But is this mutual pluralism holding?

In one sense, that pluralism is still alive. Critical sociology's best known criticism centred on the mainstream's alleged conservatism, but the environment surrounding the mainstream has long sent a very different message. As Best (2001) notes, when sociology is criticized outside of the academy, it is usually for quite opposite reasons - it is accused of being overly political and lacking in rigour. If this is the case, we may expect to see a growing emphasis on social science research methods in the mainstream. And today, much of the mainstream (especially in the United States) is dominated by survey techniques. But some mainstreamers are hailing multimethod strategies and other hybrids, such as Charles Ragin's comparative analysis (Abbott 2004; Axinn and Pearce 2006; Jacobs 2005), and, in a sense, these developments represent a process of "correction" within the mainstream.

In other ways, sociology's plurality of methods is becoming less integrated. To gauge trends, I examined the titles of all articles published in the journals Sociological Methodology and Sociological Methods and Research during the decade 1998-2008. While one might fully expect to see emphases on research technique in those journals, it is striking to witness the sheer gulf between scholars who read and publish in these outlets, versus critical scholars who might read journals such as Social Epistemology, Social Text, or Critical Sociology. The two mainstream methods journals contain several dozens of articles on statistical procedures and models, such as longitudinal analysis, missing data, causal inference, hierarchical data, age-period-cohort designs, ordinal or categorical measures, and so on. These journals are clearly influenced by many interdisciplinary trends, but their influences come overwhelmingly from other social sciences, particularly social statistics (as seen in a variety of techniques), economics (particularly for econometric strategies to infer causality) and psychology (particularly for measurement issues). They apply those techniques to bread and butter mainstream topics, such as political attitudes, status attainment, neighbourhood effects, and crime trends. Quite notably, these journals are almost entirely oblivious to trends in the humanities. I did not see a single article on literary criticism, discourse analysis, or feminist methods. Only a few papers mentioned history and anthropology; these were "positivist" discussions generalizing from case studies, and focused on the challenges facing those approaches, rather than any challenges posed by those approaches. One paper (Roth and Mehta 2002) acknowledged debates about positivism, but only in the context of triangulation strategies. Overall, these two 
journals focus overwhelming on the social science aspects of sociology, not its humanities side.

In contrast, critical sociology is more fully rejecting that kind of mainstream "scientism." While critics since C. Wright Mills have blamed social science for encouraging scholars to focus on trivial topics, obsessing with tedious issues of measurement, ignoring actors' meanings and social context, or engaging in futile efforts to quantify a social world that is constantly in flux, the critical camp has largely abandoned statistical methods completely. Instead, it avows qualitative or historical approaches in a bolder voice, less concerned with longstanding justifications for qualitative methods. One hears fewer justifications that qualitative techniques allow researchers to get "closer to reality" by gaining "insider status" or by capturing actor's true meanings and intentions, and fewer calls for techniques to establish trust, conduct interviews, check facts, or develop coding categories.

Today's critical sociologists increasingly justify their methods in political terms, in polemical and occasionally militaristic language. The mainstream methodologist is increasingly portrayed as "Eurocentric," "male," "regressive," "hegemonic," "oppressive," "arrogant," "colonial," "unjust," "elitist," "silencing," "dull-minded," "exclusionary," "marginalizing," and "subjugating" (for telling examples, see Leech 2007; Smagorinsky 2007). Longstanding concerns over technique are relegated to the sidelines, and in some extreme cases, qualitative methods are celebrated as acts of guerrilla warfare against an oppressive status quo. For instance, consider the third edition of the neutral-sounding Sage Handbook of Qualitative Research, edited by Norman Denzin and Yvonna Lincoln (2005). Of its forty-two substantive chapters, eleven have the terms "politics" or "political" in their title. Six chapters contain the term "critical," three have "justice," and others use words like "revolutionary," "progressive," "reform," "moral," "conservatism," or phrases like "inciting culture," "freeing ourselves," and "emancipating." This is the case even in the section with the seemingly technical title "Methods of Collecting and Analyzing Empirical Materials." Throughout the entire volume, only twelve chapters have technical-sounding titles, and none use terms like "validity," "reliability," or "accuracy." This understanding of methods moves the teaching of research from seemingly innocuous discussions of technique to more polarizing and divisive terms. The old language of pluralism is being replaced with one of embattled purism, serving to shrink the common methodological ground between mainstream and critical sociologists.

This trend, it should be noted, is more about issues of positivism than about the quantitative-qualitative divide per se. Qualitative research 
in the mainstream has long been concerned not only with meaning, but also with issues of research design, sample size, and generalizability, as seen in works by Elijah Anderson, Gary Alan Fine, Michele Lamont, Annette Lareau, and Diane Vaughan. Qualitative mainstreamers are now being urged to further clarify their standards, as evidenced by the US National Science Foundation (see www.wjh.harvard.edu/nsfqual/). This agenda of forging consistent standards of evidence and rigour in qualitative research places greater importance on technique, design, and causal explanation, and downplays the ethos of thick description (Schneider and Keesler 2007). This movement for rigour and standards is pushing mainstream qualitative sociology further from its critical counterpart, and towards social science.

A similar trend is occurring in quantitative research. Since policy, from health care to education to criminal justice to social welfare, is now to be "evidence based" (see de Broucker and Sweetman 2002), what counts as evidence is dictated by professional social science, particularly economics. Quantitative studies are now to be designed to identify causal patterns, and to suggest "best practices" for all sorts of social services, from teaching to nursing to social work to psychology to medicine. This pressure further entrenches a social scientific template in universities and the surrounding research community, as seen in calls for causal and counterfactual reasoning (see Morgan and Winship 2007). This development, also originating from economics, not only spreads the use of econometric techniques such as instrumental variables and propensity score matching, but also challenges researchers to think seriously about their research designs and their capacity to identify causation. The logic of experiments, a research technique long abandoned by sociologists (save a few social psychologists), is reviving with a vengeance. Research bodies in training, education, health care, and welfare studies are hailing randomized and controlled field trials as the "gold standard" by which to judge social scientific evidence.

Whatever one thinks of their merits, these trends challenge mainstream sociology's identity as a multimethod discipline. Even though avowed "positivists" such as Jonathan Turner (2005) and Randall Collins (1989) have never associated any one empirical method with good science, and readily recognize value in qualitative work, they need to respond to this new climate with invention. If the wider environment continues to tout experiments as the "gold standard" and embrace an econometric disdain for "mere" description, mainstream sociology's distinct tradition of methodological pluralism will be under pressure. Though the future is unclear, the mainstream will probably not choose to abandon its methodological tradition in favour of a humanities-based stance. 


\section{Substantive Fields: Breaking from Established Research Traditions?}

Despite these diverging trends in theories and methods, critical and mainstream sociologists may continue to address similar research topics and questions, simply approaching them with different styles. While it is a daunting task to summarize a discipline's major subfields, in this section I offer some preliminary illustrations, and suggest that amid a mixed bag of trends, the core topics pursued by mainstream and critical camps are also diverging in important ways.

Major summaries of Canadian sociology up to the late 1980s (e.g., Brym and Fox 1989) used categories familiar to the ASA mainstream, and focused on studies of social mobility, status attainment, ethnicity, regional disparities, party politics, and voting. Canadian sociology also had substantial ASA-like studies of major institutions, including criminology, education, and health care, even though such work was not particularly "Canadian" in character. During the 1980s, the growth of Marxism and antipositivist social theory moved Canadian sociology away from middle-range theories and studies, and towards rather abstract macro levels, or towards micro emphases on identity and subjectivity.

For instance, the dominance of Marxist theories of the state in the 1980s (see van den Berg 1988), diverted Canadian political sociology from longstanding questions of party formation, electoral trends, and class voting, first towards critiques of the expansion of the capitalist state, and then to laments for the decline of the (welfare) state and the rise of neoliberalism. Followers of Foucault moved in another direction, proclaiming the "governmentality" of modernity, and creating a brand of sociology that was both grander and vaguer than typical mainstream work (Fox 1998).

Another popular, but very different, vein of critical sociology was exported to Canada from Britain in the 1980s. In the 1970s, Birmingham's Centre for Contemporary Cultural Studies famously abandoned social science theories and methods in favour of literary studies, and soon produced a massive, chart-topping hit: Paul Willis' Learning to Labour (1977). ${ }^{12}$ That book portrayed school-rejecting lads in the English industrial midlands through the lens of cultural Marxism, eventually becoming a sacred text in critical scholarship. It also attracted many citations in the mainstream, but for the sake of my interest in intellectual integration, two aspects of Willis's book are crucial. First, by studying school rebels, it entered a terrain that was already much travelled

12. For a recent reminder of the CCCS's rejection of mainstream sociology and the ongoing hostility of cultural studies towards the mainstream, see Jacobs (2008). 
by mainstream sociologists of youth subcultures, class inequalities in education, and classroom processes, in both Britain and the USA. Yet, Willis barely acknowledged any of that prior research. He attempted to explain "why working class kids get working class jobs" without seriously considering any prevailing theories of educational inequality (see Davies 1995). Second, Willis's subsequent fame in the 1980s and 1990s did not stem from his substantive account of class culture, youth identity, or school processes. Learning to Labour was instead hailed for its metatheorizing about structure, agency, and cultural resistance. By reframing the book in this manner, Willis's followers could downplay questions of his empirical accuracy and logical coherence as irrelevant and beside the point. Who cared whether Willis's account made sense to researchers in the area, since the task for critical scholars was now to theorize, not to fret over empirical trivia. A resistance theorist could now be handsomely rewarded for theorizing, whether or not it was informed by existing sociological research on its topic.

Willis's book spearheaded the rise of Canadian cultural studies in the 1980s and 1990s, forging a popular brand of scholarship that lured many critical academics from their familiar territories of trade unions, social movements, or political parties to the world of popular culture. Since Learning to Labour, hundreds of cultural studies scholars have scoured all corners of everyday life, collecting a huge cache of counterhegemons: ravers, tattoo artists, d.j.'s, pornographers, bloggers, knitters, strippers, book clubbers, night clubbers, and fans of Dungeons and Dragons, Buffy the Vampire Slayer, Fight Club, and Keanu Reeves. Critical sociology certainly became more entertaining in the process. While some critical sociologists still study real-world political venues such as women's shelters and antiglobalization movements, cultural studies has enticed many of their colleagues to topics that are relatively distant from the mainstream.

By the 1990s, the combination of grand, macro critical stances and social theories of subjectivity was gaining ground. Consider 1992s Fragile Truths, an official publication meant to celebrate the 25th birthday of the Canadian Sociology and Anthropology Association. Despite their ritualistic task, the editors chose not to commemorate the sociological tradition. Instead, they declared most extant sociology to be narrow, naive, ethnocentric, masculine, and generally outmoded in a postmodernist world. They largely limited their praise to socialist feminist scholarship and activism, and declared the real intellectual action to lie in subaltern standpoints, along with the sympathies of antiracists, postmodernists, and perhaps a few reconstructed Marxists. Armed with this epistemology, the editors proclaimed mainstream sociology to be dethroned, de- 
centred, and debunked. An intellectual separatism was congealing in Canada.

A decade later, Ogmundson (2002) could catalogue an entire "cornucopia" of research streams that were largely fading in Canadian sociology, including the study of social mobility, social class, stratification, party politics, elites, the welfare state, regional development, and nationalism. These macrostructural issues were once the bread and butter of Canadian sociology, and they were addressed by many scholars beyond the mainstream. But as the new generation of critical recruits grew averse to any sort of quantification, fewer researchers outside of a small number of mainstream departments were attracted to these "traditional" topics. Most ominously, Ogmundson noted that the Porter tradition, so celebrated by Canada's political economy school, was now almost abandoned.

This argument should not be overstated; processes of drift create a gradual tendency, not a vacuum-sealed separation. Consider two contemporary textbook readers on social inequality in Canada with almost identical titles. One assumes a mainstream empirical perspective (Grabb and Guppy 2009), while the other takes a critical approach (Zawilski and Levine-Rasky 2005). What does this difference in approach entail? In the mainstream book, 20 of 28 chapters have statistical tables and graphs, and all chapters attempt to generalize to national or international levels. Few rely on case studies. The mainstream book covers hallmark topics such as "stratification," "cultural capital," "social capital," "social mobility," "occupational attainment and aspirations," and "individualism." In contrast, only 4 of 22 chapters in the critical book contain any statistical tables or graphs. While the books share some overlapping topics such as poverty, the critical reader makes more liberal use of case studies, and uses newer terminology such as "postmodernism," "essentialism," "intersectional theorizing," "essentialist colonial discourse," "critical whiteness studies," "periphrastic space," and "globalized regime of ruling." Beyond this difference in language and tone, the critical book also covers fewer of sociology's mainstream research traditions on socioeconomic status and measures of inequality, and instead places more emphasis on subjectivity and identity. Despite their differences, these books, taken as exemplars of their respective approaches, may be signalling a coming disciplinary division of labour, though it remains unclear whether they have enough commonality to correct one another.

Overall, this discussion of venues, theories, methods, and substantive areas suggests that critical sociologists have dug their own niche in Canadian universities, coexisting with the mainstream. Although operating under the same roof, branches of the discipline are growing in separ- 
ate directions. Critical sociology is building an institutionally complete academic venue that is geared towards the humanities, sometimes housing its own networks, conferences, journals, presses, job titles, and standards of evaluation. Mainstream sociology, older and more established, continues to evolve towards the social sciences. Thus, one set of forces is pulling the mainstream in one direction and another is tugging the critical camp in a different direction. Each camp appears to be largely impervious to major criticisms voiced by the other. Each can ignore the other in print and carry out its teaching and research in mutual isolation. If this portrait is accurate, there may be little prospect for the kind of mutual correction that is central to Burawoy's proposal.

\section{Conclusion: Possible Scenarios for Public Sociology in Canada}

This paper has described an institutional drift within Canadian sociology. If this analysis is correct, there may be important consequences for any future promotion of public sociology in this country. What might be the likely fallout in the discipline from the creation of tenure-stream positions and professional rewards for activism and/or public engagement? In the final section I address these questions, based on the assumption that any public sociologist in this country would be likely aligned to the critical pole of the spectrum. Judging by the voluminous literature on the topic, most of Burawoy's supporters take a critical approach, have unflattering views of the American mainstream, and are firmly rooted in the political left. Some of Burawoy's (2005c) own comments suggest that he indeed sees public sociology as a needed counterweight to a dominant American mainstream, and most of his examples of public sociologists are left-leaning activists. Since sociology in Canada is generally further to the left than it is in the United States, it is difficult to imagine any department hiring someone with overtly conservative views. Given this assumption, how might public sociology play out in Canada? Could it become a vehicle to bridge the two solitudes, encouraging critical sociologists and mainstreamers to each be more responsive and accommodating to one another? Below I outline possible scenarios for public sociology in Canada.

\section{Scenario One: Stable Nonintegration}

In one scenario, public sociology would have little impact one way or another. Sociology would continue to be governed in common administrative units in universities, sharing office space and corridors, even as its scholarly substance drifts apart. This possibility is based on a mundane 
idea: departments do not need to be cohesive and mutually correcting wholes in order to carry out their work. One sometimes hears a sentiment in Canadian sociology to the effect that formal intellectual disputes have little bearing on scholars' 9-5 lives. Don't be uptight. You say tomato, and I'll say tomato. If one further believes that disciplinary structures represent mere administrative conveniences that have been arbitrarily slapped together over the decades, then a lack of integration is to be expected, and notions of mutual correction are simply naive. A variant of this argument is that scholars today are interested more in their particular speciality than in their discipline as a whole. Indeed, for some Canadian sociologists, if there is to be any change at all, it should be to further dilute sociology and incorporate even more disparate forms of scholarship. One might add, as long as undergraduates fill our enrolment sheets and bring large tuition dollars, administrators certainly don't care! Taking this even further, some attack notions of common standards as a veiled imperialism and reactionary identity politics (e.g. Carroll et al. 1992). Overall, these varied opinions underlie some of the responses to McLaughlin's (2005) essay on coming crises in Canadian sociology.

One could back up this sentiment by pointing to Canadian departments that have successfully implemented a bifurcated system of evaluating the respective scholarship of critical sociologists and mainstreamers. The ability to use very different criteria for hiring and tenuring in the same administrative unit is a striking testament to organizational flexibility in academe. Some departments informally allow dissimilar standards of scholarship to coexist by insulating schools of thought from each other. Overall, in this scenario, any new tensions that may result from the promotion of public sociology could be organizationally managed, as long as mainstream sociologists are relatively oblivious to any new critical public sociologists, and as long as scholars working in the same departmental units remain cooperative with each other. Canadian sociology could continue on its present course without encountering any undue crises that could weaken its place in universities. This is the scenario that I believe is most likely.

\section{Scenario Two: Reintegration through Reconciliation or Evolution}

In a different scenario, an infusion of public sociology would prompt sociologists to seek a form of reconciliation. Some sociology departments have image problems in universities where they are seen to be overly fractious, or where administrators wonder if sociology is really a distinct discipline at all. But while some Canadian sociology departments had virtual warfare in the 1970s and 1980s, today's battles are usually 
quite mild in comparison. Both mainstream and critical camps would embrace Burawoy's warning that the academic climate may become less forgiving of nonintegrated disciplines, and eventually agree to speak with a united voice when faced by incursions by university administrators. But as I have argued above, the challenges facing Canadian sociology are somewhat different from those facing its American counterpart. Addressing the Canadian scene, McLaughlin (2005) has recommended that sociologists purposively engage in a sort of reconciliation. He suggests an exchange program where critical scholars might attend the annual meetings of the ASA, for instance, and where mainstreamers could reciprocate in various ways. Bryant (1992), with a different motive, has suggested that sociologists should receive graduate training in the philosophy of science, reasoning that positivistic empirical researchers would benefit from exposure to antipositivist positions. In this scenario, a public sociologist could play the role of the bridge-builder, perhaps by highlighting compatibilities between different approaches rather than reminding us of our differences.

In a similar scenario, integration could be enhanced in a less purposeful manner, and through a more evolutionary process. An irony of institutional drift is that divisions between critical and mainstream sociology are increasingly academic in nature, and reflect fewer real political differences beyond the university. Perhaps even those academic disputes could be contained. One source of containment is that critical stances have become less extreme over time. As critical sociology gets institutionalized in academe, much of the moral fervour and inspirational charisma that originally fuelled divisions between critical and mainstream scholars is dissipating. Many scholars have abandoned links to extreme and volatile political movements beyond the academy. Whereas some vocal critical sociologists in previous eras were members of pro-Soviet Communist parties, Maoist groups, communes, or underground sects that espoused violence (such as Marlene Dixon [1976]), few of today's critical sociologists have comparable politics. Far fewer fights in Canadian sociology erupt over burning issues of the day, such as the Iraq War, Afghanistan, Quebec separatism, the Israeli-Palestinian conflict, poverty, or violent crime. Indeed, traditional leftists like Noam Chomsky (1995) and Todd Gitlin (1995) have lamented the distance of postmodernists from the rough and tumble world of actual politics. In the realm of epistemology, the much-heralded "postpositivist" brand of metatheorizing seems to represent a tempering of an old antagonism towards the mainstream (van den Berg 2006). Similarly, battles over the place of feminism are less intense than in previous eras, since women are now better represented in most departments, and freely teach courses 
in gender or women studies if they so choose. Many critical sociologists endorse the liberal politics of "inclusion" rather than revolution, if even they use the idioms of the latter to voice the former. Much of critical sociology has thus been transformed from a charismatic, morally driven "permanent revolution" to a professional movement with its own takenfor-granted norms, as happened to mainstream sociology in a previous era. Racial representation may be the remaining political frontier, since the small numbers of tenure-stream hires in Canadian sociology in recent years have not nearly kept pace with rapidly changing demographics. All in all, the politics that once generated the critical-mainstream divide have become increasingly abstract and removed from real world struggles. More passions in the seminar room are inflamed by rarefied debates over empirical technique, epistemology, or terminology than real-world politics, and those passions may be easily contained..$^{13}$

A second source of containment is the flexibility of mainstream sociology. Mainstreamers such as Collins (1989) have attempted to synthesize ideas from a variety of perspectives, including the humanitiesoriented, into a broadly scientific sociology. Indeed, one could view an evolutionary process at work in which many challenges are eventually absorbed into the mainstream. New upstarts initially face uncompromising opposition from established approaches, but over time are granted niches within the discipline, and even blend easily into mainstream. For instance, Canadian studies courses were initially implemented in the 1970s to ensure a minimal level of Canadian content in sociology programs, given perceptions that American materials dominated the curriculum. Some boasted that such courses could eventually topple American approaches and create a new paradigm. Over the years, many departments have eliminated those courses, assured that their sociology is safely and soundly Canadian. Likewise, some departments are now (quietly) questioning the need for sociology of women courses, noting the discipline's responsiveness to gender issues over the decades, and the centrality of gender analyses in some of its substantive areas. While some feminists continue to demand a complete overhaul of sociology's intellectual core (e.g., Ferree et al. 2007), others are quietly content with the reforms that have emerged. Maybe postmodernists and postcolonialists will have similar fates if some of their ideas filter further into the mainstream. Thus, in this scenario, previously hostile camps gradually can temper their mutual complaints as new approaches become securely

13. McAdam (2007) speculates that the rise of the "hard left" in the discipline during the 1970 s and 1980s created a disdain for pragmatic and practical politics, with the unintended consequence of discouraging sociologists from tackling topics that would otherwise engage the broader public. 
established, and the mainstream evolves to accommodate new perspectives.

\section{Scenario Three: Distorting Public Sociology through Rebranding}

A less plausible scenario is one in which public sociology is captured by a small homegrown movement to "rebrand" Canadian sociology. Canada's rebranders ${ }^{14}$ share some of Burawoy's worries about the continuing viability of sociology in today's academic climate, but advocate a more opportunistic and less principled response. Rather than encouraging sociologists to collectively defend and bolster their tradition, they call for short-term strategies that combine a fashionable "postdisciplinarity" pandering to the ever-changing whims of university administrators, with the mindset of commercial advertisers. Aiming to secure a large undergraduate population, they urge departments to repeatedly shift their hiring and teaching priorities to ever-changing administrator agendas, and to dilute and even eliminate challenging courses in theory and methods. They believe (rightly) that many undergraduates shy from difficult courses that are not required, and also believe (wrongly) that being an easy major ensures a stable place in the academy. Their vision is to use public sociology to remarket our intellectual wares into a "fantasy discipline" that lures credential-seeking students with promises of lite entertainment, and appeases administrators with logos, mission statements, and tuition revenues.

The rebranders are unlikely to be successful, since most Canadian sociologists eschew such corporate thinking. Some recognize that successful "businesses" can enhance their reputations not only through slick advertising campaigns, but also by quality control and the courting of discriminating buyers. Very few Canadian sociologists want the discipline to devolve into a rebranded, generic "service" curriculum for disengaged undergraduates (for a similar warning that is not limited to sociology, see Côté and Allohar 2006).

\section{Scenario Four: Pushing Towards a Split?}

A final scenario, one that is unlikely but not impossible, could emerge if public sociology is promoted in a way that exacerbates the current process of institutional drift. As discussed above, infighting in Canadian sociology in previous eras took a particular form in which combatants

14. The "rebranders" are a small network of older white males who in recent years have been unelected affiliates of the Canadian Sociology Association and the Canadian Review of Sociology. Their agenda is loosely based on an uncritical social constructionism that draws from currents in marketing and advertising. It is little coincidence that one of their heroes, Steve Woolgar, is now Chair of Marketing at Oxford. 
fought intensely, but in a common arena. Through departmental management and forms of reconciliation and containment, many old flames have been doused. But if public sociology becomes another vehicle to denigrate sociology as a scientific pretender, the mainstream may react in a less accommodating fashion than it has in the past. A public form of antipositivism would be harder to absorb, since it would challenge the mainstream's intellectual heart and institutional support base. A misplaced form of public sociology could deepen this antagonism in today's competitive academy, with its limited resources for social science. For instance, mainstreamers may balk if a public sociologist portrays the discipline to the mass media as firmly committed to the relativism of standpoint and postmodernist approaches. Think of recent episodes in which mainstreamers have not come to the public defence of critical scholars, such as the Social Text hoax by left-wing physicist Alan Sokal, the parodies of novelist David Lodge, the "bad writing" prizes awarded to postmodernists, and the sneering of "tenured radicals" by the mass media. An escalation of antipositivism into the public realm may be difficult for the mainstream to accommodate. As Alan Sokal (Bricmont and Sokal 1999) has noted, the scientific outlook is about seeking debate and truth, rather than intellectual peace or compromise per se. He confesses little interest in either waging war or brokering peace vis-à-vis his detractors, since in his eyes, incompatible views should be reconciled via evidence and logic, not through compromise or some sort of deal. To the extent that mainstreamers share this outlook, any reconciliation with more public versions of antipositivism could be strained in today's context. Unlike thirty years ago, contemporary sociologists are now risking the loss of previously important research traditions to "harder" social sciences, particularly economics. Some mainstreamers worry that tasks previously done in-house by sociologists are migrating elsewhere, such as statistical studies of income inequality (e.g., Myles 2003; Myles and Myers 2007). In my own area, Canadian sociologists have mostly conceded quantitative studies of education to economists. Other sociological traditions are being picked up psychologists, political scientists, and researchers from business and health sciences. If public sociology promotes an image of the discipline that makes it less recognized as a social science, there is a potential danger that it will depend more on its teaching function to survive in universities, and be further vulnerable to the whims of administrators (Turner 2005). The mainstream might see critical public sociology as a threat to its status as a social science.

Anticipating this possibility, sociologists such as Jonathan Turner (2006) have called for a disciplinary divorce. In this scenario, critical and mainstream sociologists would each form their own departments, with 
the former committed to humanities-based work, and the latter committed to science-aimed inquiry. New mainstream departments would still be very diverse, housing qualitative, quantitative, and historical sociologists, theorists of various stripes, and individuals with an assortment of political convictions, but would commonly believe that sociology offers a unique approach to social inquiry, differing from economics by its alternative assumptions about human rationality and the nature of social institutions, and by its use of a variety of research methods. They would see it differing from psychology by its insistence on the causal primacy of contextual factors. They would also see sociology as differing from the humanities by its use of empirical techniques to study the social world.

Which of these four possible scenarios is most likely? One way to address this question is to conduct further research on the topic. Sociologists could gather existing work on the historical trajectories of fields that have been beset with profound intellectual differences. A good starting place is the emerging specialty in the sociology of knowledge that examines academic disciplines, schools of thought, and fields of study (e.g., Frickel and Gross 2005; Siler and McLaughlin 2008; Whitley 2000). Using its insights, researchers could anticipate the impact of public sociology by examining how other disciplines balance their professional cores with their public outreach. Researchers could check the historical record of other loosely integrated fields, seeing if they survive, and if other previously divided fields have successfully reintegrated. It would be particularly intriguing to see if such examples exist beyond the natural sciences, where paradigmatic divisions are far less intense, the convictions of Kuhn's followers notwithstanding. Are there instances of purposeful reconciliation, where proponents of opposed schools have consciously resolved their intellectual beefs? If so, what strategies appeared to have worked? What was the nature of the surrounding context? Alternatively, what has been the historical aftermath of those disciplines that split and went their own way? At the very least, research on these questions can make for an intriguing dissertation. At best, it can shed light on whether public sociology can integrate the discipline in an increasingly uncertain academic world.

\section{REFERENCES}

Abbott, Andrew. 2004. Methods of Discovery: Heuristics for the Social Sciences. New York: W.W. Norton and Co.

Acker, J. 2005. Comments on Burawoy on public sociology. Critical Sociology 31(3):327-332. 
Agger, Ben. 1991. Critical theory, poststructuralism, postmodernism: Their sociological relevance. Annual Review of Sociology 17:105-31. 2007. Public Sociology: From Social Facts to Literary Acts (second edition). Lanham, MD: Rowman and Littlefield Publishers Inc.

Axinn, William G. and Lisa D. Pearce. 2006. Mixed Method Data Collection Strategies. Cambridge: Cambridge University Press.

Babbie, Earl. 2006. The Practice of Social Research (11th edition). Wadsworth.

Beck, Ulrich. 2005. How not to become a museum piece. British Journal of Sociology 56(3):335-343.

Best, Joel. 2001. Social progress and social problems: Toward a sociology of gloom. Sociological Quarterly 42:1-12.

Bottomore, Tom. 1984. The Frankfurt School. London: Horwood.

Bourdieu, Pierre and Loïc J.D. Wacquant. 1992. An Invitation to Reflexive Sociology. Chicago: University of Chicago Press.

Bowles, Samuel and Herbert Gintis. 1976. Schooling in Capitalist America. New York: Basic Books.

Braverman, Harry. 1974. Labor and Monopoly Capital: The Degradation of Work in the Twentieth Century. New York: Monthly Review.

Bricmont, Jean and Alan Sokal. 1999. Science and sociology of science: Beyond war and peace. Accessed on July 3, 2008 at http://www.physics.nyu.edu/ faculty/sokal/collins v4b clean.ps.

Brint, Steven. 2005. Guide for the perplexed: On Michael Burawoy’s "public sociology." The American Sociologist 36(3-4):46-65.

Bryant, Joseph M. 1992. Positivism redivivus? A critique of recent uncritical proposals for reforming sociological theory (and related foibles). Canadian Journal of Sociology 17:29-53.

Brym, Robert with Bonnie Fox. 1989. From Culture to Power: The Sociology of English Canada. Toronto: Oxford University Press.

Burawoy, Michael. 2005a. 2004 Presidential Address: For public sociology. American Sociological Review 70(1):4-28. 2005b. Third wave sociology and the end of pure science. The American Sociologist Fall-Winter:152-165. 2005c. Rejoinder: Toward a critical public sociology. Critical Sociology 31(3):379-390.

Calhoun, Craig and Jonathan Van Antwerpen. 2007. Orthodoxy, heterodoxy, and hierarchy: "Mainstream" sociology and its challengers. Pp. 367-410 in Craig Calhoun, ed., Sociology in America: A History. Chicago: University of Chicago Press.

Carroll, William, Linda Christiansen-Ruffman, Raymond F. Currie, and Deborah Harrison, eds. 1992. Fragile Truths: Twenty-Five Years of Sociology and Anthropology in Canada. Toronto: University of Toronto Press. 
Cheal, David. 2003. Family: Critical Concepts in Sociology. London: Routledge.

Chomsky, Noam. 1995. Noam Chomsky on postmodernism. Accessed at http:// cscs.umich.edu/ crshalizi/chomsky-on-postmodernism.html on November 25, 2008.

Collins, Randall. 1989. Sociology: Pro-science or anti-science? American Sociological Review 53:124-139.

Cormier, Jeffrey. 2004. The Canadianization Movement: Emergence, Survival, and Success. Toronto: University of Toronto Press.

Côté, James and Anton Allohar. 2006. Ivory Tower Blues. Toronto: University of Toronto Press.

Davies, Scott. 1995. Leaps of faith: Shifting currents in critical sociology of education. American Journal of Sociology 100(6):1448-1478.

de Broucker, Patrice and Arthur Sweetman. 2002. Towards Evidence-Based Policy for Canadian Education. Montreal: McGill-Queens University Press.

Deflem, Mathieu. 2007. Public sociology, hot dogs, apple pie and Chevrolet. Journal of Professional and Public Sociology (inaugural issue). Downloaded November 25, 2008 at http://www.cas.sc.edu/socy/faculty/ deflem/zpubsocapple.html.

Dekeseredy, Walter and Barbara Perry, eds. 2006. Advancing Critical Criminology. Lanham, MD: Lexington Books.

Denzin, Norman and Yvonna S. Lincoln. 2005. The Sage Handbook of Qualitative Research. Newbury Park, CA: Sage Publications.

Dixon, Marlene. 1976. Things which are Done in Secret. Montreal: Black Rose.

Ericson, Richard. 2005. Publicizing sociology. British Journal of Sociology 56(3):365-372.

Ferree, Myra Marx, Shamus Rahman Khan, and Shauna A. Morimoto. 2007. Assessing the feminist revolution: The presence and absence of gender in theory and practice. Pp. 438-479 in Craig Calhoun, ed., Sociology in America: A History. Chicago: University of Chicago Press.

Fox, Nick J. 1998. Foucault, Foucauldians and sociology. British Journal of Sociology 49(3):415-433.

Frickel, Scott and Neil Gross. 2005. A general theory of scientific/intellectual movements. American Sociological Review 70(2):204-232.

Gartrell, David and John W. Gartrell. 1996. Positivism in sociological practice: 1967-1990. Canadian Review of Sociology and Anthropology 33:143158.

Gene Expression. 2008. Graphs on the death of Marxism. Accessed on September 28, 2008 at http://www.gnxp.com/blog/2008/09/graphs-on-death-ofmarxism.php. 
Gitlin, Todd. 1995. The Twilight of Common Dreams. New York: Holt.

Goldthorpe, John H. 1994. The uses of history in sociology: A reply. The British Journal of Sociology 45(1):55-77.

Grabb, Edward and Neil Guppy. 2009. Social Inequality in Canada: Patterns, Problems, and Policies. Toronto: Pearson Prentice-Hall.

Hammersley, Martin. 2005. Should social science be critical? Philosophy of the Social Sciences 35(2):175-195.

Hargens, Lowell L. 2000. Using the literature: Reference networks, reference contexts, and the social structure of scholarship. American Sociological Review 65(6):846-865.

Helmes-Hayes, Rick. 2002. John Porter: Canada's most famous sociologist and his links to American sociology. The American Sociologist 33(1):79-104.

Horowitz, Irving Louis. 1993. The Decomposition of Sociology. New York: Oxford University Press.

Jacobs, Jerry A. 2005. Multiple methods in ASR. Footnotes 33:9 (December):1,4.

Jacobs, Mark. 2008. Message from the chair: Cultural sociology and cultural studies. Retrieved at http://www.ibiblio.org/culture/?q=node/16 on November 26, 2008.

Kirby, Sandra, Lorraine Greaves, and Colleen Reid. 2006. Social Research Experiences Change: Methods Beyond the Mainstream. Toronto: University of Toronto Press.

Kolakowski, Leszek. 1978. Main Currents of Marxism. Volume 3. The Breakdown. London: Oxford University Press.

Lamont, Michèle and Virag Molnar. 2002. The study of boundaries in the social sciences. Annual Review of Sociology 28:167-95.

Leech, Nancy. 2007. Research and the "inner circle": The need to set aside counterproductive language. Educational Researcher 36(4):200-202.

McAdam, Doug. 2007. From relevance to irrelevance: The curious impact of the sixties on public sociology. Pp.411-426 in Craig Calhoun, ed., Sociology in America: A History. Chicago: University of Chicago Press.

McLaughlin, Neil. 2005. Canada's impossible science: Historical and institutional origins of the coming crisis in Anglo-Canadian sociology. Canadian Journal of Sociology 30:1-40.

McLaughlin, Neil, Lisa Kowalchuk, and Kerry Turcotte. 2005. Why sociology does not need to be saved: Analytic reflections on public sociologies. The American Sociologist (Fall-Winter):133-151.

Michalski, Joseph H. 2005. La diversité épistémologique de la sociologie canadienne: Quelques éléments de comparaison entre professeurs Francophones et professeurs Anglophones. Le Cahier de l'ACSALF 2(2):2-3. 
Mills, Albert J., T. Simmons, and J. Helms Mills. 2005. Reading Organization Theory: Critical Approaches to the Study of Behaviour and Structure in Organizations. Third Edition. Toronto: Garamond Press.

Moody, James. 2004. The structure of a social science collaboration network: Disciplinary cohesion from 1963 to 1999. American Sociological Review 69(2):213-238.

Morgan, Stephen L. and Christopher Winship. 2007. Counterfactuals and Causal Inference. New York: Cambridge University Press.

Myles, John. 2003. Where have all the sociologists gone? Explaining economic inequality. Canadian Journal of Sociology 28(4):553-561.

Myles, John and Karen Myers. 2007. Who gets what and why? Answers from sociology. American Behavioral Scientist 50(5):579-583.

Neilson, Francois. 2004. The vacant we: Remarks on public sociology. Social Forces 82(4):1619-1627.

Ogmundson, Richard. 2002. The Canadian case: Cornucopia of neglected research opportunities. The American Sociologist 33(1):55-78.

Rinehart, James. 2005. The Tyranny of Work: Alienation and the Labour Process (fifth edition). Scarborough, ON: Nelson Education.

Roth, Wendy and Jal Mehta. 2002. The Rashomon effect: Combining positivist and interpretivist approaches in the analysis of contested events. Sociological Methods and Research 31(2):131-173.

Satzewich, Vic and Nick Liodakis. 2006. Race and Ethnicity in Canada. A Critical Introduction. Toronto: Oxford University Press.

Schneider, Barbara and V.A. Keesler. 2007. School reform 2007: Transforming education into a scientific enterprise. Annual Review of Sociology 33:197-217.

Siler, Kyle and Neil McLaughlin. 2008. The Canada Research Chairs Program and social science reward structures. Canadian Review of Sociology 45(1):93-119.

Smagorinsky, Peter. 2007. A thick description of thick description. Educational Researcher 36(4)199-200.

Stacey, Judith and Barrie Thorne. 1986. The missing feminist revolution in sociology. Social Problems (32).

Steckley, John and Guy Letts. 2006. Elements of Sociology: A Critical Canadian Introduction. Toronto: Oxford University Press.

Steinmetz, George. 2007. American sociology before and after World War II. Pp. 314-366 in Craig Calhoun, ed., Sociology in America: A History. Chicago: University of Chicago Press. 2006. Reply to Axel van den Berg. The Canadian Journal of Sociology Online, May-June. Accessed on July 3, 2008 at http://www.cjsonline.ca/ reviews/politicsmethod.html. 
Turner, Jonathan. 2005. Is public sociology such a good idea? The American Sociologist 36(3-4):27-45.

Van den Berg, Axel. 2006. Review forum: The politics of method in the human sciences. The Canadian Journal of Sociology Online, May-June. Accessed on July 3, 2008 at http://www.cjsonline.ca/reviews/politicsmethod.html.

1988. The Immanent Utopia. Princeton, NJ: Princeton University Press.

Wacquant, Loïc. 2002. Scrutinizing the street: Poverty, morality, and the pitfalls of urban ethnography. American Journal of Sociology 107(6):1468-1532.

Whitley, Richard. 2000. The Intellectual and Social Organization of the Sciences (second edition). Oxford: Clarendon.

Willis, Paul. 1977. Learning to Labour: How Working Class Kids Get Working Class Jobs. Westmead UK: Saxon House.

Winant, Howard. 2007. The dark side of the force: One hundred years of the sociology of race. Pp. 535-571 in Craig Calhoun, ed., Sociology in America: A History. Chicago: University of Chicago Press.

Wotherspoon, Terry. 2004. Sociology of Education in Canada: Critical Perspectives (second edition). Toronto: Oxford University Press.

Zawilski, Valerie and Cynthia Levine-Rasky. 2005. Inequality in Canada: A Reader on the Intersections of Gender, Race and Class. Don Mills, ON: Oxford University Press Canada.

Scott Davies is Professor of Sociology and Ontario Research Chair in Educational Achievement and At-Risk Students, Offord Centre for Child Studies, McMaster University. He has published sociological articles in Canadian, American and British journals. His books include The Schooled Society, co-authored with Neil Guppy (Oxford University Press, 2006) and The Globalization of School Choice, co-edited with Martin Forsey and Geoffrey Walford (Symposium Books, 2008). He is also an associate editor of Canadian Public Policy, and is on the editorial boards of Sociology of Education, American Journal of Education, and Sociological Inquiry. 